\title{
PENERAPAN MODEL PEMBELAJARAN KOOPERATIF TIPE THINK TALK WRITE (TTW) DAN TIPE THINK PAIR SHARE (TPS) PADA MATA KULIAH STATISTIK EKONOMI I DI PROGRAM STUDI EKONOMI MANAJEMEN STIMI MEULABOH
}

\author{
Nur Fajri ${ }^{1}$, Hardianto Zainal $^{2}$ \\ STIMI Meulaboh ${ }^{1}$, Politeknik Aceh Selatan ${ }^{2}$ \\ nurfajri.ifar@gmail.com
}

\begin{abstract}
Abstrak
Penelitian ini adalah penelitian eksperimen yang bertujuan untuk mengetahui perbedaan hasil belajar mahasiswa yang diajarkan dengan pembelajaran kooperatif tipe TPS dan mahasiswa yang diajarkan dengan pembelajaran kooperatif tipe TTW pada mata kuliah Statistika Ekonomi I di Program Studi Ekonomi Manajemen STIMI Meulaboh. Subjek penelitiannya adalah mahasiswa peserta mata kuliah Statistik Ekonomi Sekolah Tinggi Ilmu Manajemen Indonesia (STIMI) Meulaboh. Data dalam penelitian ini dikumpulkan dengan menggunakan soal tes setelah mahasiswa diajarkan dengan menggunakan model pembelajaran tipe TTW dan TPS. Analisis data menggunakan uji statistik (uji-t). Pengujian hipotesis menggunakan uji dua pihak dengan kriteria pengujian: "Terima H0 jika $\mathrm{t}<\mathrm{t}(1-\alpha)$ dan tolak H0 jika t mempunyai hargaharga lain. Derajat kebebasan untuk daftar distribusi $t$ ialah $(n 1+n 2-2)$ dengan peluang $(1-\alpha)$ dan $\alpha=0,05$. Sebelum uji-t dilakukan terlebih dahulu diuji syarat-syaratnya, yaitu uji normalitas dan homogenitas. Berdasarkan hasil penelitian diperoleh bahwa Tidak terdapat perbedaan hasil belajar mahasiswa yang diajarkan dengan model pembelajaran kooperatif tipe TPS dan model pembelajaran kooperatif tipe TTW pada mata kuliah Statistika Ekonomi I di Program Studi Ekonomi Manajemen STIMI Meulaboh
\end{abstract}

Kata Kunci: pembelajaran kooperatif; TTW; TPS; Statistika Ekonomi

Abstract

The research is an experimental research that aims to analyze the difference of learning points by using the cooperative learning models between Think Pair Share (TPS) and Think Talk Write (TTW) types in Economic Statistic 1 courses in Department of Management Economics of STIMI Meulaboh. The population of this research is the students who took economic statistic 1 courses in Department of Management Economics of STIMI Meulaboh. The data were collected by test after students were taught using the TTW and TPS type learning models. The data of this research conducted through test statistic (t-test). Hypothesis testing uses two-tailed test with criteria: "H0 accepted variable values included within the range $t<t(1-\alpha)$ and a rejection if $t$ out of the acceptance range. The $t-$ distribution with $(\mathrm{n} 1+\mathrm{n} 2-2)$ degress of freedom $(\mathrm{dF})$ with odds $(1-\alpha)$ and $\alpha=$ 0.05 . Before the t-test is carried out, normality and homogeneity tests were come first as the requirements tested. Based on the results was found that there were not difference of learning points by using the cooperative learning models between Think Pair Share (TPS) and Think Talk Write (TTW) types in Economic Statistic 1 courses in Department of Management Economics of STIMI Meulaboh.

Keyword: cooperative learning; TTW; TPS; Economic Statistic I 


\section{PENDAHULUAN}

Salah satu cara yang dapat digunakan dosen untuk mengaktifkan proses belajar mengajar di kelas yaitu dengan menerapkan model pembelajaran kooperatif (cooperative learning). Dalam model pembelajaran tersebut mahasiswa tidak ditempatkan sebagai objek pembelajaran, akan tetapi sebagai subjek dalam kegiatan pembelajaran. Dalam penelitian ini, peneliti mengambil dua pembelajaran kooperatif yaitu pembelajaran kooperatif tipe think-pair-share (TPS) dan pembelajaran kooperatif tipe think-talk-write (TTW).

Pembelajaran kooperatif tipe TPS merupakan pembelajaran kooperatif yang dirancang untuk mempengaruhi pola interaksi mahasiswa, struktur yang dikembangkan ini dimaksudkan sebagai alternatif terhadap struktur kelas tradisional. Pembelajaran kooperatif tipe TPS dimulai dengan memberikan masalah kepada mahasiswa (think) kemudian menyelesaikan masalah secara berpasangan (pair) dan mahasiswa diminta untuk membagikan ide (share) kepada teman lainnya. Menurut [1] bahwa pembelajaran kooperatif tipe TPS merupakan model pembelajaran kooperatif yang menempatkan siswa secara berpasangan untuk menyelesaikan tugas akademik melalui tiga tahap, yakni: think (berpikir), pair (berpasangan), dan share (berbagi).

Pembelajaran kooperatif tipe TTW merupakan strategi yang diharapkan dapat menumbuh kembangkan pemahaman dan komunikasi matematika mahasiswa. Alur kemajuan strategi TTW dimulai dari keterlibatan mahasiswa dalam berpikir (thinking) atau berdiskusi dengan dirinya sendiri setelah proses membaca, selanjutnya berbicara dan membagi ide (sharing) dengan temannya sebelum menulis. Suasana seperti ini lebih efektif jika dilakukan dalam kelompok heterogen dengan 3-5 mahasiswa. Menurut [2] bahwa think-talk-write (TTW) adalah model pembelajaran yang berusaha membangun pemikiran merefleksi, dan mengorganisasi ide, kemudian menguji ide tersebut sebelum siswa diharapkan untuk menuliskan ide-ide tersebut.

Pemilihan kedua model ini didasarkan pada observasi awal penulis ketika mengajar di Program Studi Ekonomi Manajemen STIMI Meulaboh, di mana model pembelajaran kooperatif tipe TPS dan tipe TTW belum pernah diterapkan dalam proses belajar mengajar khususnya untuk mengajar mata kuliah Statistika Ekonomi I. Selain itu, penulis juga memperoleh informasi bahwa kebanyakan mahasiswa semester II Program Studi Ekonomi Manajemen masih memiliki kendala dalam menyelesaikan permasalahan pada mata kuliah Statistika Ekonomi I dikarenakan mata kuliah tersebut mengandung masalah-masalah yang penyelesaiannya membutuhkan analisis yang tinggi, sehingga mahasiswa kesulitan dalam memahaminya.

Menurut [3] model pembelajaran kooperatif adalah prosedur yang berurutan dalam proses belajar dengan memanfaatkan teman sejawat (siswa lain) sebagi sumber belajar untuk mencapai tujuan pendidikan. Selanjutnya [4] menyatakan bahwa model pembelajaran kooperatif adalah bentuk kegiatan pembelajaran dengan cara siswa belajar dan bekerja dalam kelompok kecil secara kolaboratif yang terdiri dari empat sampai enam orang dengan struktur kelompok yang heterogen. Metode pembelajaran Cooperative Learning dapat: (a) mengajarkan mahasiswa menjadi percaya kepada dosen; (b) kemampuan berpikir; (c) mencari informasi dari sumber lain dan belajar dari mahasiswa lain; (d) 
mendorong mahasiswa untuk mengungkapkan idenya secara verbal dan menbandingkan dengan ide temannya; (e) membantu mahasiswa untuk belajar saling menghormati mahasiswa yang pintar dan mahasiswa yang kurang serta dapat menerima perbedaan tersebut [5].

Tujuan penelitian ini untuk mengetahui perbedaan hasil belajar mahasiswa yang diajarkan dengan pembelajaran kooperatif tipe TPS dan mahasiswa yang diajarkan dengan pembelajaran kooperatif tipe TTW pada mata kuliah Statistika Ekonomi I di Program Studi Ekonomi Manajemen STIMI Meulaboh.

\section{METODE}

Adapun jenis penelitian ini adalah penelitian kuantitatif. Menurut [6] menyatakan penelitian kuantitatif banyak dituntut menggunakan angka, mulai dari pengumpulan data, penafsiran data serta penampilan dari hasilnya. Pendekatan dalam penelitian ini adalah pendekatan eksperimen. Salah satu jenis design eksperimen ialah True Eksperimental Design dengan pola:

Keterangan:

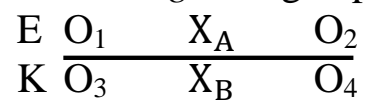

E adalah kelompok eksperimen (TTW)

$\mathrm{K}$ adalah kelompok kontrol (TPS)

$\mathrm{X}_{\mathrm{A}}$ dan $\mathrm{X}_{\mathrm{B}}$ adalah perlakuan

$\mathrm{O}_{1}$ dan $\mathrm{O}_{3}$ adalah nilai pre-test

$\mathrm{O}_{2}$ dan $\mathrm{O}_{4}$ adalah nilai post-test

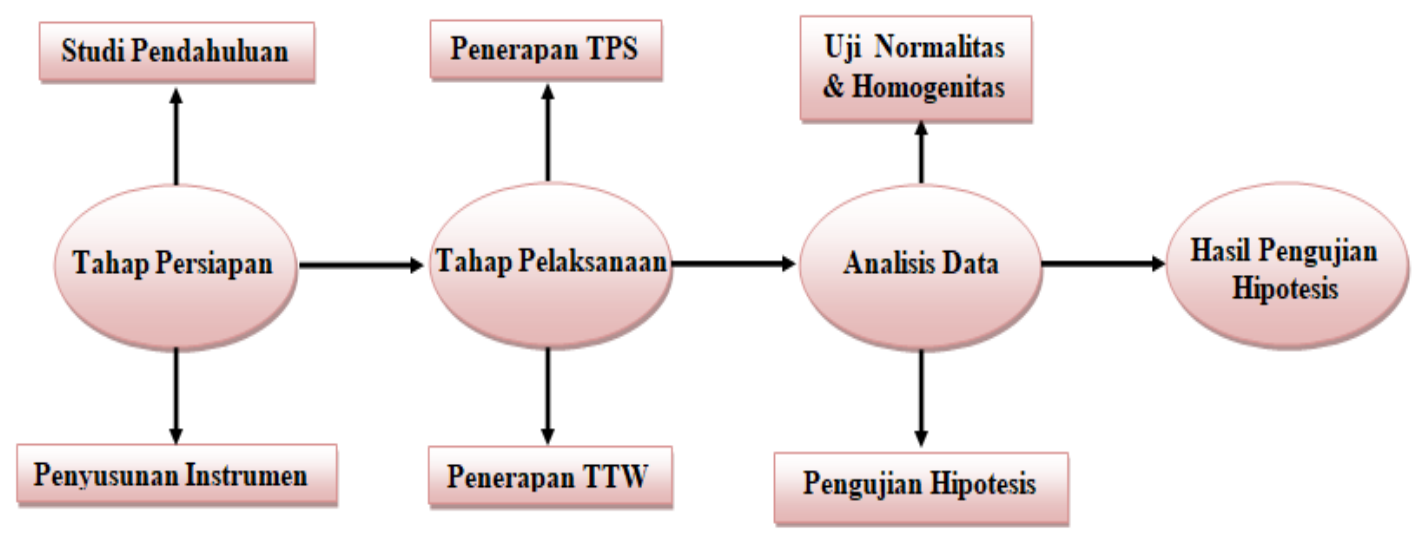

Gambar 1. Prosedur penelitian

Adapun prosedur Penelitian ini adalah a) tahap persiapan, b) tahap pelaksanaan, c) tahap analisis data, dan d) Hasil pengujian hipotesis. Prosedur penelitian digambarkan pada Gambar 1.

\section{HASIL DAN PEMBAHASAN}

Penelitian ini dilakukan pada mahasiswa semester 2 pada matakuliah statistik ekonomi I di STIMI Meulaboh yang terdiri dari 2 kelas. Untuk mengetahui perbedaan hasil belajar siswa antara yang diajarkan dengan model TPS dengan model TTW, peneliti memberi soal preetest dan postest kepada mahasiswa. Data yang diperoleh akan di uji kenormalan, homogenitas dan uji hipotesis 
Adapun data tes akhir yang diperoleh dari hasil penelitian dapat dilihat pada gambar berikut ini

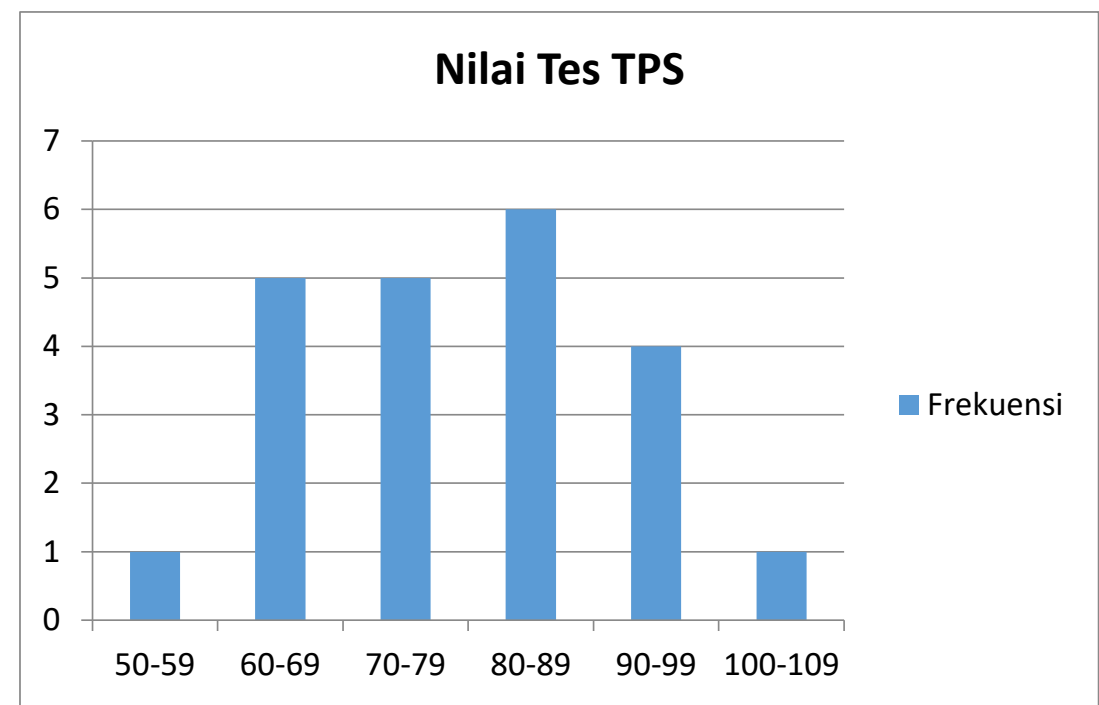

Gambar 2. Nilai Test TPS

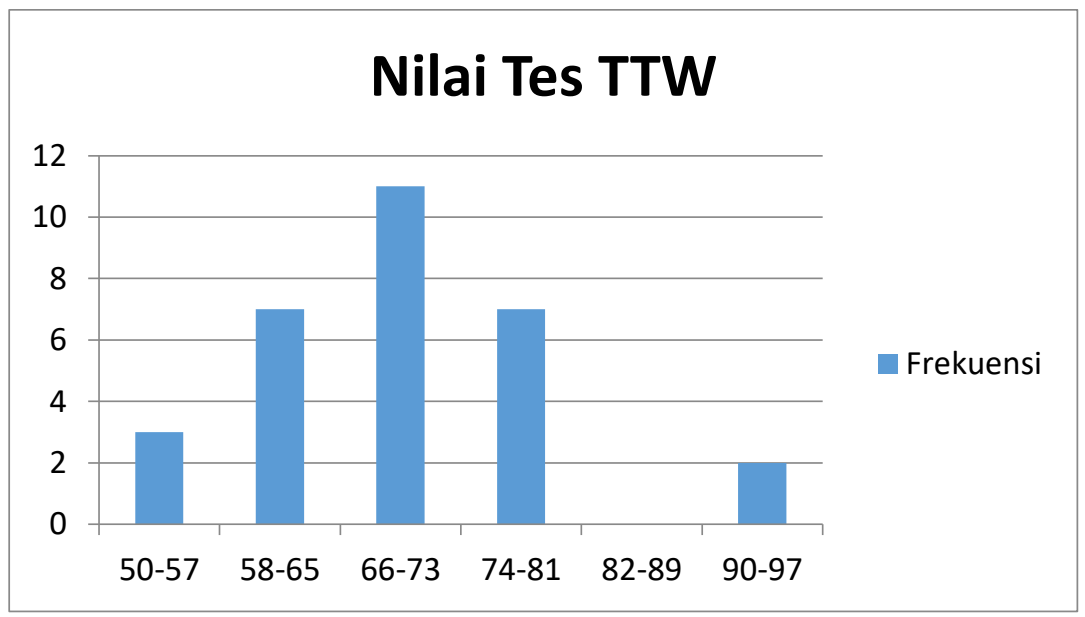

Gambar 3. Nilai Test TTW

\section{Uji Normalitas}

Uji normalitas sebaran data bertujuan untuk mengetahui apakah data dari masing-masing kelompok dalam penelitian ini berasal dari populasi yang berdistribusi normal atau tidak. Berdasarkan nilai tes akhir penerapan model pembelajaran TPS diperoleh nilai $\bar{x}=79,1, \mathrm{~s}_{1}{ }^{2}=158,76$ dan $\mathrm{s}_{1}=12,6$. Sedangkan untuk data kelas TTW diperoleh $\bar{x}=69,5, \mathrm{~s}_{1}{ }^{2}=92,16$ dan $\mathrm{s}_{1}=9,6$. Selanjutnya perlu ditentukan batas-batas kelas interval untuk menghitung luas di bawah kurva normal bagi tiap-tiap kelas interval. 
Tabel 1. Uji Normalitas Sebaran Data Tes Akhir Kelas TPS

\begin{tabular}{|c|c|c|c|c|c|c|}
\hline Nilai tes & $\begin{array}{l}\text { Batas } \\
\text { Kelas } \\
\text { (x) }\end{array}$ & $\begin{array}{c}\text { Z- } \\
\text { score }\end{array}$ & $\begin{array}{l}\text { Batas } \\
\text { Luas } \\
\text { Daerah }\end{array}$ & $\begin{array}{c}\text { Luas } \\
\text { Daerah }\end{array}$ & $\begin{array}{c}\text { Frekuensi } \\
\text { diharapkan } \\
\left(\mathrm{E}_{\mathrm{i}}\right)\end{array}$ & $\begin{array}{c}\text { Frekuensi } \\
\text { Pengamatan } \\
\left(\mathrm{O}_{\mathrm{i}}\right) \\
\end{array}$ \\
\hline & 49,5 & $-2,34$ & 0,4904 & & & \\
\hline $50-59$ & 59,5 & $-1,55$ & 0,4394 & 0,051 & 1,122 & 1 \\
\hline $60-69$ & 69,5 & $-0,76$ & 0,2764 & 0,163 & 3,586 & 5 \\
\hline $70-79$ & 79,5 & 0,03 & 0,0120 & 0,2644 & 5,8168 & 5 \\
\hline $80-89$ & 89,5 & 0,83 & 0,2967 & 0,2847 & 6,2634 & 6 \\
\hline $90-99$ & 99,5 & 1,62 & 0,4474 & 0,1507 & 3,3154 & 4 \\
\hline $100-109$ & 109,5 & 2,41 & 0,4920 & 0,0446 & 0,9812 & 1 \\
\hline Jumlah & - & - & - & 0,9584 & 21,08 & 22 \\
\hline
\end{tabular}

Tabel 2. Uji Normalitas Sebaran Data Tes Akhir Kelas TTW

\begin{tabular}{ccccccc}
\hline Nilai tes & $\begin{array}{c}\text { Katas } \\
\text { Kelas } \\
(\mathrm{x})\end{array}$ & $\begin{array}{c}\text { Z- } \\
\text { score }\end{array}$ & $\begin{array}{c}\text { Batas } \\
\text { Luas } \\
\text { Daerah }\end{array}$ & $\begin{array}{c}\text { Luas } \\
\text { Daerah }\end{array}$ & $\begin{array}{c}\text { Frekuensi } \\
\text { diharapkan } \\
\left(\mathrm{E}_{\mathrm{i}}\right)\end{array}$ & $\begin{array}{c}\text { Frekuensi } \\
\text { Pengamatan } \\
\left(\mathrm{O}_{\mathrm{i}}\right)\end{array}$ \\
\hline $50-57$ & 49,5 & $-2,08$ & 0,4812 & & & \\
$58-65$ & 57,5 & $-1,25$ & 0,3944 & 0,0868 & 2,604 & 3 \\
$66-73$ & 65,5 & $-0,41$ & 0,1591 & 0,2353 & 7,059 & 7 \\
$74-81$ & 73,5 & 0,41 & 0,1591 & 0 & 0 & 11 \\
$82-89$ & 81,5 & 1,25 & 0,3944 & 0,2353 & 7,059 & 7 \\
$90-97$ & 89,5 & 2,08 & 0,4812 & 0,0868 & 2,604 & 0 \\
\hline Jumlah & - & - & - & 0,9584 & 21,08 & 30 \\
\hline
\end{tabular}


Maka nilai chi-kuadrat hitung untuk kelas TPS adalah sebagai berikut:

$X^{2}=\sum_{i=1}^{k} \frac{\left(O_{i}-E_{i}\right)^{2}}{E_{i}}$

$X^{2}=0,8366$

Dengan taraf signifikan $\alpha=0,05$ dan banyak kelas $\mathrm{k}=5$, maka diperoleh derajat kebebasan (dk) untuk distribusi chi-kuadrat besarnya adalah $\mathrm{dk}=6-3=$ 3 , dari tabel chi-kuadrat $X^{2}{ }_{0,95}=7,81$. Oleh karena $X^{2}{ }_{\text {hitung }}<X^{2}$ tabel yaitu $(0,8366<$ 7,81) maka $\mathrm{H}_{0}$ diterima dan dapat disimpulkan bahwa sebaran data dari siswa kelas TPS mengikuti distribusi normal.

Berdasar nilai pada tabel 3 maka nilai chi-kuadrat hitung untuk kelas TTW adalah sebagai berikut:

$X^{2}=\sum_{i=1}^{k} \frac{\left(O_{i}-E_{i}\right)^{2}}{E_{i}}$

$X^{2}=7,0178$

Dengan taraf signifikan $\alpha=0,05$ dan banyak kelas $\mathrm{k}=6$, maka diperoleh derajat kebebasan (dk) untuk distribusi chi-kuadrat besarnya adalah $\mathrm{dk}=6-3=$ 3 , dari tabel chi-kuadrat $X_{0,95}^{2}=7,81$. Oleh karena $X_{\text {hitung }}^{2}<X_{\text {tabel }}^{2}$ yaitu $(7,017<$ 7,81) maka $\mathrm{H}_{0}$ diterima dan dapat disimpulkan bahwa sebaran tes akhir kelompok TTW mengikuti distribusi normal.

\section{Uji Homogenitas}

Uji homogenitas varians bertujuan untuk mengetahui apakah sampel dari penelitian ini berasal dari populasi yang sama, sehingga generalisasi dari hasil penelitian ini hasilnya berlaku secara populasi.

Hipotesis yang akan diuji pada taraf signifikan $\alpha=0,05$ yaitu:

$\mathrm{H}_{0}: \sigma_{1}{ }^{2}=\sigma_{2}^{2}:$ Varians homogen untuk kelas TPS dan kelas TTW

$\mathrm{H}_{1}:{\sigma_{1}}^{2}>\sigma_{2}{ }^{2}$ : Varians kelas TPS lebih besar dari varians kelas TTW sehingga ke dua varians tidak homogen

Maka statistik yang digunakan adalah $\mathrm{F}=\frac{\text { varians terbesar }}{\text { varians terkecil }}$

Karena pengujian ini adalah uji pihak kanan, maka kriteria pengujian "Tolak $\mathrm{H}_{0}$ jika $F_{\text {hitung }} \geq \mathrm{F} \alpha\left(\mathrm{n}_{1}-1, \mathrm{n}_{2}-1\right)$ dan terima $\mathrm{H}_{0}$ jika $\mathrm{F}$ mempunyai harga-harga lain". Berdasarkan perhitungan di atas, telah diperoleh varians dari masing-masing kelompok $\mathrm{s}_{1}{ }^{2}=158,76$ dan $\mathrm{s}_{2}{ }^{2}=92,16$ sehingga:

$$
\begin{aligned}
& \mathrm{F}=\frac{\text { varians terbesar }}{\text { varians terkecil }} \\
& \mathrm{F}=1,72
\end{aligned}
$$

Dari tabel distribusi diperoleh $F_{\alpha}\left(\mathrm{n}_{1}-1, \mathrm{n}_{2}-1\right)=\mathrm{F}_{0,05}(21,29)$

$$
=2,00
$$


Ternyata $\mathrm{F}_{\text {hitung }}<\mathrm{F}_{\text {tabel }}(1,72<2,00)$, maka $\mathrm{H}_{0}$ diterima dan dapat disimpulkan bahwa kedua varians homogen untuk tes akhir.

\section{Uji Hipotesis}

Hipotesis yang diuji yaitu:

$\mathrm{H}_{0}: \mu_{1}=\mu_{2}$ : Tidak terdapat perbedaan hasil belajar mahasiswa yang diajarkan dengan model pembelajaran kooperatif tipe TPS dan model pembelajaran kooperatif tipe TTW pada mata kuliah Statistika Ekonomi I di Program Studi Ekonomi Manajemen STIMI Meulaboh.

$\mathrm{H}_{1}: \mu_{1 \neq} \mu_{2}$ : Terdapat perbedaan hasil belajar mahasiswa yang diajarkan dengan model pembelajaran kooperatif tipe TPS dan model pembelajaran kooperatif tipe TTW pada mata kuliah Statistika Ekonomi I di Program Studi Ekonomi Manajemen STIMI Meulaboh.

Dari perhitungan sebelumnya diperoleh nilai sebagai berikut:

$$
\begin{array}{lll}
\bar{x}_{1}=79,1 & \mathrm{~s}_{1}{ }^{2}=158,76 & \mathrm{~s}_{1}=12,6 \\
\bar{x}_{2}=69,5 & \mathrm{~s}_{2}{ }^{2}=92,16 & \mathrm{~s}_{1}=9,6
\end{array}
$$

Maka nilai $t$ diperoleh sebagai berikut:

$t=\frac{\overline{x_{1}}-\overline{x_{2}}}{S \sqrt{\frac{1}{n_{1}}+\frac{1}{n_{2}}}}$

$t_{\text {hitung }}>t_{\text {tabel }}$

$0,98<2,02$

Dengan taraf signifikan $\alpha=0,05$ dan derajat kebebasan $\mathrm{dk}=\mathrm{n}_{1}+\mathrm{n}_{2}-2$ maka dari distribusi $t$ dengan cara interpolasi $\mathrm{t}_{0,975}(50)=2,02$, sehingga diperoleh $\mathrm{t}_{\text {hitung }}>\mathrm{t}_{\text {tabel }}(0,98<2,02)$ maka $\mathrm{H}_{0}$ diteriam pada taraf signifikan $\alpha=0,05$. Sehingga dapat disimpulkan bahwa, "Tidak terdapat perbedaan hasil belajar mahasiswa yang diajarkan dengan model pembelajaran kooperatif tipe TPS dan model pembelajaran kooperatif tipe TTW pada mata kuliah Statistika Ekonomi I di Program Studi Ekonomi Manajemen STIMI Meulaboh.

\section{KESIMPULAN}

Berdasarkan hasil penelitian dan pembahasan, dapat disimpulkan bahwa , "Tidak terdapat perbedaan hasil belajar mahasiswa yang diajarkan dengan model pembelajaran kooperatif tipe TPS dan model pembelajaran kooperatif tipe TTW pada mata kuliah Statistika Ekonomi I di Program Studi Ekonomi Manajemen STIMI Meulaboh. 


\section{DAFTAR RUJUKAN}

[1] Arki, A.K.H dkk. 2017. Penerapan Metode Pembelajaran Kooperatif Tipe Think-Pair-Share Untuk Meningkatkan Hasil Belajar Siswa Kelas XI MIA.2 SMA Negeri 3 Model Takalar (Studi pada Materi Pokok Larutan Asam-Basa). Jurnal Chemica. Volume 18(2), Desember 2017, Hal. 71-79. Jurusan Kimia Fakultas Matematika dan Ilmu Pengetahuan Alam: Universitas Negeri Makassar.

[2] Sugandi. 2011. Pengaruh Model Pembelajaran Kooperatif Tipe Think Talk Write Terhadap Kemampuan Pemecahan Masalah dan Koneksi Matematis. Halaman 51-59.

[3] Elhefni. 2011. Model Pembelajaran Kooperatif Tipe Think Pair Share dan Hasil Belajar di Sekolah. TA’DIB. Volume XVI(02), Edisi Nopember 2011, Hal. 303-319.Fakultas Tarbiyah IAIN Raden Fatah Palembang: Palembang.

[4] Rusman. (2013). Model-Model Pembelajaran: Mengembangkan Profesionalisme Guru. Edisi ke-2. Jakarta: PT. RajaGrafindo Persada.

[5] Kurnia, RD dkk. 2014. Pengembangan Model Pembelajaran Berbasis Cooperative Learning dalam Meningkatkan Motivasi Belajar Mahasiswa dan Peningkatan Mutu Lulusan Alumni Fasilkom Unsri Berbasis ELearning (studi kasus: matakuliah pemrograman web). Jurnal Sistem Informasi (JSI), Volume 6(1), April 2014, Hal. 645-654, ISSN Print : 20851588, ISSN Online : 2355-4614. Sistem Informasi Fakultas Ilmu Komputer Universitas Sriwijaya: Universitas Sriwijaya

[6] Arikunto, S. 2011. Penelitian Tindakan Kelas. Yogyakarta: Aditya Media.

MOHON DI EDIT DATA INI DENGAN DATA DIRI ANDA YG BENAR.

Telah menerima artikel dengan judul "Penerapan Model Pembelajaran Kooperatif Tipe Think Talk Write (TTW) dan Tipe Think Pair Share (TPS) pada Mata Kuliah Statistik Ekonomi I di Program Studi Ekonomi Manajemen STIMI Meulaboh". yang diserahkan oleh :

Nama : Nur Fajri, S. Pd., M. Si

Instansi : STIMI Meulaboh

NIDN $\quad: 1309088901$

No HP : : 082114754973

Alamat : jl. Teungku Dirundeng, lr Rajawali, Desa Rundeng, Kec. Johan

Pahlawab, Kab. Aceh Barat. NAD

MOHON DI EDIT DATA INI DENGAN DATA DIRI ANDA YG BENAR. 